\title{
Ochrona środowiska naturalnego w procesie produkcji rolnej a koncepcja własności rolniczej
}

Współczesne rolnictwo w Polsce w głównej mierze determinowane jest osiąganiem celów wskazanych we Wspólnej Polityce Rolnej² oraz wynikających z niej regulacjach krajowych. Zależy to nie tylko od przyjętych zobowiązań członkowskich w sferze prawnej, ale przede wszystkim z uwagi na kierowaną pomoc finansową dla rolników. Bez tej pomocy współczesne rolnictwo mogłoby nie sprostać konkurencji i nie miałoby możliwości zwiększyć poziomu inwestycji w rolnictwo. Jednym z głównych wyznaczników warunkujących otrzymanie tej pomocy jest spełnienie określonych wymogów. Po 2013 r. nastąpiła reforma WPR ${ }^{3}$ kładąca nacisk na uwzględnianie w procesie produkcji rolnej celów ochrony środowiska naturalnego.

Do tradycyjnych kryteriów dostępowych do pomocy, takich jak przestrzeganie zasad wzajemnej zgodności ${ }^{4}$ włączono nową ,zieloną" politykę rolną. Rolnik chcący uzyskać pomoc finansową, czy to pochodzącą z systemu płatności bezpośrednich, ${ }^{5}$ czy z funduszy przeznaczonych na rozwój obszarów wiejskich, ${ }^{6}$ jest zo-

Badania zostały sfinansowane ze środków Narodowego Centrum Nauki przyznanych w ramach finansowania stażu po uzyskaniu stopnia naukowego doktora na podstawie decyzji numer DEC-2012/04/S/HS5/00338. Uniwersytet Warszawski.

2 A. Jurcewicz, Wspólna Polityka Rolna Unii Europejskiej, [w:] Prawo rolne, P. Czechowski (red)., Warszawa 2011, s. $97-100$.

3 A. Germano, Reforma Wspólnej Polityki Rolnej z 2003 r. i reżim płatności jednolitej, „Przegląd Prawa Rolnego”, 2007, nr 1.

4 B. Jeżyńska, Znaczenie i funkcje zasady cross-compliance w systemie rolniczych dopłat bezpośrednich, „Studia luridica Lubliniensia" 2010, nr 13; A. Hawrylewicz-Łuka, Spełnianie wymogów wzajemnej zgodności (crosscomplience) przy ubieganiu się przez rolników o płatności bezpośrednie jako poszanowanie środowiska naturalnego, [w:] Administracja publiczna - człowiek a ochrona środowiska. Zagadnienia społeczno-prawne, M. Górski, J. Bucińska, M. Niedziółka, R. Stec, D. Strus (red.), Warszawa 2011, s.130-155; T. Kurowska, Zadania i funkcje instrumentów prawnych wspierania rozwoju obszarów wiejskich, „Studia luridica Agraria” 2005, t. IV; E. Kremer, Wybrane zagadnienia z problematyki rozwoju obszarów wiejskich, płatności bezpośrednich w orzecznictwie sądów administracyjnych, „Studia luridica Agraria” 2009, t. VII, s. 142-162. $5 \quad$ Wymogi prośrodowiskowe określone są w rozporządzeniu Parlamentu Europejskiego i Rady (UE) nr 1307/2013 systemów wsparcia w ramach wspólnej polityki rolnej oraz uchylające rozporządzenie Rady (WE) nr 637/2008 i rozporządzenie Rady (WE) nr 73/2009 (Dz.U. UE L 347 z dnia 20 grudnia 2013 r., s. 608 z późn. zm.) - dalej przywoływane jako rozporządzenie 1307/2013.

6 Rozporządzenie Parlamentu Europejskiego i Rady (UE) nr 1305/2013 z dnia 17 grudnia 2013 r. w sprawie wsparcia rozwoju obszarów wiejskich przez Europejski Fundusz Rolny na rzecz Rozwoju Obszarów Wiejskich (EFR- 
bowiązany do przestrzegania określonych praktyk korzystnych dla klimatu i innych szczegółowych wymogów wspierających ochronę bioróżnorodności przyrodniczej. Rolnik staje przed wyzwaniem dostosowania dotychczas prowadzonej działalności do nowych zadań i celów Wspólnej Polityki Rolnej. W przeciwnym razie nie będzie mógł korzystać praktycznie ze wszystkich rodzajów oferowanej aktualnie pomocy kierowanej do rolników. „Zielona” polityka rolna staje się warunkiem koniecznym, umożliwiającym dalsze inwestycje w sektor rolny.

Jednym z pytań, jakie się nasuwa jest koszt takich zmian. W przypadku rolników, kiedy nie wprowadzą odpowiednich prośrodowiskowych elementów nie będą mogli korzystać ze środków europejskich, przez co może się obniżyć poziom konkurencyjności ich gospodarstw na rynku. ${ }^{7} \mathrm{Z}$ pewnością element ekonomiczny zaważy na funkcjonowaniu powyższych nowych regulacji zmierzających do ochrony środowiska naturalnego. Wybór rolnika może okazać się zdeterminowany przez rachunek ekonomiczny, a nie poczucie dobrze wykonywanego zawodu - rolnika indywidualnego. ${ }^{8}$ Zbyt wysokie wymagania i ograniczenia stawiane potencjalnym beneficjentom mogą nie tylko zniechęcić ich do starania się o pomoc, ale także spowodować regres w rozwoju ich gospodarstw. Na marginesie należy zauważyć, że wysokość przyznawanej pomocy nie jest jednym z motywatorów do wprowadzania proekologicznych ${ }^{9}$ zmian. Obecnie płatność za zazielenienie wynosi 304,31 zł/ha. ${ }^{10}$ Kwota ta może okazać się zbyt nieatrakcyjną dla rolników, którzy mieliby przeznaczyć część swoich gospodarstw na trwałe użytki zielone, czy też obszary proekologiczne.

Ważniejszym jednak elementem, od kwestii ekonomicznych, ${ }^{11} \mathrm{z}$ punktu widzenia prawa wydaje się określenie stopnia ingerencji nowych regulacji w prawo wła-

ROW) i uchylające rozporządzenie Rady (WE) nr 1698/2005 (Dz.U. UE L 347 z dnia 20 grudnia 2013 r., s. 487 z późn. zm.). Znajduje tutaj również zastosowanie rozporządzenie delegowane Komisji (UE) z dnia 11 marca 2014 r. uzupełniające rozporządzenie Parlamentu Europejskiego i Rady (UE) nr 1305/2013 w sprawie wsparcia rozwoju obszarów wiejskich przez Europejski Fundusz Rolny na rzecz Rozwoju Obszarów Wiejskich (EFRROW) i wprowadzające przepisy przejściowe (Dz.U. UE L 227 z dnia 31 lipca 2014 r., s. 1 z późn. zm).

7 J. Stoksik, Wybrane zagadnienia ochrony interesów finansowych Unii Europejskiej w dziedzinie Wspólnej Polityki Rolnej, „Studia luridica Agraria” 2012, t. X, s. 424-442; A.Z. Nowak, A. Niewiadomska, Wpływ funduszy strukturalnych na wzrost konkurencyjności polskiego rolnictwa - wybrane aspekty ekonomiczne, „Studia luridica Agraria” 2012, t. X, s. 307-325; P. Czechowski, A. Niewiadomski, Wpływ funduszy strukturalnych na wzrost konkurencyjności polskiego rolnictwa - aspekty prawne, „Studia luridica Agraria” 2012, t. X, s. 326-334; W. Czubak, W. Poczta, A. Sadowski, Wpływ proponowanej reformy systemu dopłat bezpośrednich po 2013 roku na sytuację polskiego rolnictwa, „Wieś i rolnictwo” 2011, nr 4.

$8 \quad$ M.A. Król, A. Niewiadomski, Rodzinne gospodarstwa rolne w systemie prawnym ochrony środowiska i zrównoważonego rozwoju, [w:] Ekonomiczne i prawne mechanizmy wspierania i ochrony rolnictwa rodzinnego, M. Podstawka (red.), Warszawa 2015, s. 240-255; A. Niewiadomski, Rodzinne gospodarstwo rolne wobec ochrony środowiska w prawie polskim i europejskim, [w:] Prawne mechanizmy wspierania i ochrony rolnictwa rodzinnego w Polsce i innych państwach Unii Europejskiej, P. Liwtiniuk (red.), Warszawa 2015, s. 141-151.

9 B. Jeżyńska, Proekologiczne instrumenty wsparcia zrównoważonego rozwoju obszarów Wiejskich, „Studia luridica Agraria", Białystok 2012, t. X, s. 251-264.

10 http://www.minrol.gov.pl/Wsparcie-rolnictwa/Platnosci-bezposrednie/Archiwum/Platnosci-bezposrednie-w2015-r/Wysokosc-platnosci-bezposrednich-stosowanych-w-2015-r.

11 G. Anderson, J. Śleszyński, Ekonomiczna wycena środowiska przyrodniczego, [w:] Wartościowanie dóbr i zasobów środowiska, J. Śleszyński (red.), Białystok 1996. 
sności nieruchomości. ${ }^{12}$ Nie ulega wątpliwości, że wprowadzenie nowych wymogów związanych z ochroną przyrody ogranicza właściciela nieruchomości rolnych - rolnika w wykonywaniu jego prawa. Nakłada na niego obowiązki podjęcia odpowiednich środków i kroków dostosowawczych pod groźbą nieprzyznania pomocy finansowej. Ograniczenia prawa własności ${ }^{13}$ polegają m.in. czy to na dywersyfikacji upraw, tworzeniu trwałych użytków zielonych, ${ }^{14}$ obszarów proekologicznych, ${ }^{15}$ czy w końcu wdrażaniu praktyk korzystnych dla klimatu.

Regulacje publicznoprawne wymuszają w tym zakresie na rolniku podjęcie lub zaniechanie odpowiednich działań w odniesieniu do nieruchomości rolnej będącej w jego władaniu. W zamian za tak wprowadzone ograniczenia rolnikowi oferowana jest pomoc finansowa, która ma mu rekompensować poniesione ciężary w związku z dostosowaniem swojego gospodarstwa do funkcjonowania w nowych warunkach. Pytanie oczywiście o adekwatność wysokości zaplanowanej rekompensaty w stosunku do wprowadzonych i zaakceptowanych ograniczeń. W dłuższej perspektywie respektowanie zasad ochrony środowiska naturalnego oraz zachowanie bioróżnorodności ma zwiększyć nie tylko dochodowość działalności rolniczej, ale także wy-

12 E. Ura, K. Heliniak, Ograniczenia własności nieruchomości w administracyjnym prawie materialnym, [w:] Jednostka wobec działań administracji publicznej, E. Ura (red.), Rzeszów 2001; F. Longchamps, Ograniczenia własności nieruchomości w polskim prawie administracyjnym, „Przegląd Prawa i Administracji” 1939, nr 1-2; M. Szewczyk, Ingerencja publicznoprawna w prawo własności jednostki w demokratycznym państwie prawnym, [w:] Jednostka w demokratycznym państwie prawa, J. Filipek (red.), Bielsko-Biała 2003; W. Radecki, Ograniczenie własności ze względu na potrzeby szczególnej ochrony przyrody, [w:] Ochrona środowiska a prawo własności, J. Sommer (red.), Wrocław 2000, s. 29 i nast.

13 O innych ograniczeniach prawa własności por. przykładowo: A. Zieliński, Zagadnienia prawa własności w orzecznictwie Naczelnego Sądu Administracyjnego, „Kwartalnik Prawa Prywatnego” 1993, nr 4, s. 411-446; B. Zdziennicki, Reprywatyzacja w świetle zasad prawa, „Studia Prawnicze” 2015, nr 3, s. 5-34; W. Borysiak, Ochrona własności a nadużycie prawa, „Studia luridica” 2010, nr 52, s. 17-39; D. Kokoszka, Gospodarstwo rolne. Zagadnienia konstrukcyjne, „Kwartalnik Prawa Prywatnego” 2008, nr 4, s. 985-1042; M. Gocłowski, Posiadanie w ujęciu kodeksu cywilnego (Prawo podmiotowe czy stan faktyczny?), „Państwo i Prawo” 2001, nr 2, s. 44-62; R. Waśniewski, Pracownicze ogrody działkowe w prawie cywilnym i rolnym, „Państwo i Prawo” 2000, nr 5, s. 75-85; S. Wójcik, Problem pojęcia „własność prywatna” w III Rzeczypospolitej, „Rejent” 1991, nr 7; M. Budzikowski, Ograniczenia praw podmiotowych właściciela nieruchomości rolnej w prawie administracyjnym, „Studia luridica” 2014, nr 58, s. 31-43; E. Gniewek, O prawie własności - w kontekście prac Komisji Kodyfikacyjnej Prawa Cywilnego, „Rejent” 2008, nr 2, s. 54-67.

14 Przykładowo można tylko wskazać na szczegółowość regulacji, którym muszą się poddać rolnicy chcący uzyskać pomoc finansową. Zgodnie z art. 2 ust. 1 lit. h rozporządzenia 1307/2013 za trwałe użytki zielone uznano "grunty wykorzystywane do uprawy traw lub innych pastewnych roślin zielnych rozsiewających się naturalnie (samosiewnych) lub uprawianych (wysiewanych), które nie były objęte płodozmianem danego gospodarstwa rolnego przez okres pięciu lat lub dłużej; mogą one obejmować inne gatunki, takie jak krzewy lub drzewa, które mogą nadawać się do wypasu, pod warunkiem że zachowano przewagę traw i innych pastewnych roślin zielnych, a także - w przypadku gdy zadecydują tak państwa członkowskie - grunty, które mogą nadawać się do wypasu i które stanowią część utrwalonych praktyk lokalnych w przypadkach, gdy trawy i inne zielne rośliny pastewne tradycyjnie nie są roślinnością dominującą na obszarach wypasu".

15 Za obszary proeokologiczne państwo członkowskie UE może uznać: obszary ugorowane, elementy krajobrazu, włączając elementy położone na obszarze przylegającym do działki kwalifikowanej, strefy buforowe bez nawożenia i pestycydów, włączając strefy buforowe pod trwałymi użytkami zielonymi, na których może być prowadzony wypas i koszenie, międzyplony lub pokrywę zieloną (wg współczynnika ważenia), uprawy wiążące azot, obszary pod zagajnikami o krótkiej rotacji, systemy rolno-leśne, pasy działki przylegające do krawędzi lasu, obszary zalesione zgodnie z PROW, uprawy trwałe z obsadą więcej niż 20 drzew, ale nie przekraczającą 250 szt./ha, uprawy trwałe na stokach o nachyleniu 10 proc. lub więcej, obszary objęte praktykami równoważnymi do zazielenienia. Ponadto należy zauważyć, że obowiązek wyłączeń gruntów rolnych pod obszary proekologiczne nie będzie dotyczył tych gospodarstw, które co najmniej na 75\% gruntów mają użytki zielone, uprawiają trawy lub pasze zielone, odłogują grunty lub uprawiają strączkowe. 
datnie wpłynąć na jakość produktów rolnych. Na razie brak jest informacji mierzalnych i sprawdzalnych, które mogłyby potwierdzić powyższe założenia.

Z możliwością ograniczenia praw właściciela nieruchomości rolnej na rzecz ogółu społeczeństwa spotykamy się w koncepcji własności rolniczej Andrzeja Stelmachowskiego. ${ }^{16}$ Koncepcja ta sformułowana zakłada, że „błędem byłoby dziś ujmowanie własności li tylko jako prawa podmiotowego. Własność jest raczej kompleksem praw i obowiązków. [...] Kto wie, czy korelacja praw i obowiązków typowa dla praw obligacyjnych, nie powinna być także traktowana w zakresie praw bezwzględnych. Własność jest więc prawem skutecznym wobec ogółu, ale i ograniczonym ze względu na potrzeby ogółu". ${ }^{17}$ Pozwala to na dokonywanie różnych ograniczeń praw właściciela nieruchomości w celu zaspokojenia potrzeb ogółu. W tym zakresie związane jest to nie tylko z opisanymi powyżej regulacjami europejskimi dotyczącymi ochrony środowiska naturalnego, ale także z podejmowaniem przez organy administracji publicznej innych czynności, które ograniczają właściciela w jego prawie.

Do takich ograniczeń można chociażby zaliczyć ustanowienie na danym terenie jednej z dziesięciu form ochrony przyrody określonych w ustawie o ochronie przyrody, ${ }^{18}$ czy też wprowadzenie ograniczeń w aktach planowania przestrzennego, takich jak chociażby miejscowe plany zagospodarowania przestrzennego. ${ }^{19}$ Przyglądając się bliżej tym ograniczeniom i analizując chociażby wymienione powyżej plany, czy plany ochrony parków narodowych, ${ }^{20}$ czy też plany zadań ochronnych dla obszarów Natura $2000^{21}$ wyraźnie można wskazać, iż w celu osiągniecia odpo-

16 T. Kurowska, Współczesne aspekty własności rolniczej, „Studia luridica Agraria” 2002, t. III, s. 39-50.

17 A. Stelmachowski, Wstęp do teorii prawa cywilnego, Warszawa 1969, s. 227-228; A. Stelmachowski, Zarys teorii prawa cywilnego, Warszawa 1998, s. 206; Wpływ instrumentów prawnych na przestrzenną strukturę rolnictwa, A. Stelmachowski (red.), Warszawa 1977; A. Stelmachowski, Współczesne zróżnicowanie własności, „Studia luridica Agraria" 2002, t. III, s. 17-38.

Zgodnie z art. 6 ust. 1 ustawy o ochronie przyrody „Formami ochrony przyrody są: parki narodowe; rezerwaty przyrody; parki krajobrazowe; obszary chronionego krajobrazu; obszary Natura 2000; pomniki przyrody; stanowiska dokumentacyjne; użytki ekologiczne; zespoły przyrodniczo-krajobrazowe; ochrona gatunkowa roślin, zwierząt i grzybów".

19 Ustawa z dnia 27 marca 2003 r. o planowaniu i zagospodarowaniu przestrzennym (Dz.U. z 2015 r., poz. 199 z późn. zm.).

20 P. Czechowski, A. Niewiadomski, Selected legal issues of modern forms of environmental protection on the example of national parks and the networks of Natura 2000 sites, taking into account coexistence with agriculture, "Studia luridica" 2015, t. 61, s. 35-52; Z. Bukowski, Wybrane uwarunkowania prawne odnoszące się do obszarów Natura 2000 stanowiących park narodowy, [w:] Problemy wdrażania systemu Natura 2000 w Polsce, A. Kaźmierska-Patrzyczna, M.A. Król (red.), Szczecin - Łódź - Poznań 2013, s. 159-167; P. Czechowski, A. Niewiadomski, Natura 2000 a parki narodowe - wybrane problemy prawne, [w:] Administracja publiczna a ochrona przyrody. Zagadnienia ekonomiczne, społeczne oraz prawne, M. Górski, D. Niedziółka, R. Stec, D. Strus (red.), Warszawa 2012, s. 101-116; P. Czechowski, A. Niewiadomski, National parks and Natura 2000 areas - evaluation of the legal status of regulations in rural areas, [w:] Chosen Problems of Nature Conservation in Polish and International Law, P. Litwiniuk, A. Niewiadomski, R. Stec, Ł. Ciołek (red.), Warszawa 2015, s. 23-32; J. Ciechanowicz McLean, Parki Narodowe w prawnym systemie ochrony przyrody, [w:] Administracja publiczna a ochrona przyrody. Zagadnienia ekonomiczne, społeczne oraz prawne, M. Górski, D. Niedziółka, R. Stec, D. Strus (red.), Warszawa 2012, s. 117-124.

21 K. Piekut, B. Pawluśkiewicz, Stan i perspektywy utrzymania obszarów Natura 2000 na terenach rolniczych, [w:] Problemy wdrażania systemu Natura 2000 w Polsce, A. Kaźmierska-Patrzyczna, M.A. Król (red.), Szczecin Łódź - Poznań, 2013, s. 665-684; M.A. Król, Sytuacja prawna prowadzącego działalność rolniczą na obszarach 
wiedniego poziomu ochrony przyrody i bioróżnorodności ustawodawca wprowadza liczne ograniczenia w wykonywaniu prawa własności nieruchomości, łącznie z zakazem prowadzenia działalności rolniczej. Takie praktyki w świetle koncepcji własności rolniczej wydają się dopuszczalne. Rolnik jest zobowiązany do wykonywania określonych obowiązków względem społeczeństwa, a obowiązki te składają się na część prawa własności, są jego immamentną cechą.

Według koncepcji własności rolniczejej ${ }^{22}$ rolnik oprócz prawa do dysponowania swoją nieruchomością zgodnie z jej społeczno-gospodarczym przeznaczeniem powinien mieć świadomość o istnieniu innych ograniczeń. Jak wskazano powyżej są one wprowadzone poprzez system prawa publicznego, a ich uzasadnieniem jest dobro społeczne - w tym przypadku ochrona środowiska naturalnego. Rolnik będący częścią społeczeństwa powinien znosić wprowadzane ograniczenia nie tylko z uwagi na prowadzoną działalność, ale także z myślą o losie przyszłych pokoleń. Tak rozumiana rola rolnika wiąże się z jego tradycyjną rolą ochrony ziemi i dbania o jej płody ziemi. Specjalny status rolnika wymaga od niego poniesienia pewnych ciężarów związanych z posiadaną własnością na rzecz ogółu.

Opisane ograniczenia wynikające z nowej ,zielonej” polityki rolnej, czy też funkcjonowania szeregu przepisów dotyczących ochrony jakościowej i ilościowej obszarów cennych przyrodniczo pozwalają założyć, że na współczesne prawo własności rolniczej składa się szereg uprawnień związanych z prowadzoną działalnością rolniczą oraz określone obowiązki względem państwa i społeczeństwa. W kontekście omawianej tematyki ochrony środowiska naturalnego na te ograniczenia będzie składało się podporządkowanie wprowadzanym regulacjom i takie wykonywanie swojego prawa własności, aby w jak najmniejszy sposób nie pogorszyć stanu przyrody. Wszelkie działania ochronne i aktywności rolnika, takie jak dywersyfikacja upraw, tworzenie obszarów proekologicznych również są częścią składową współczesnej własności rolniczej. Ograniczenia te dzielą się na dobrowolne i przymusowe. Dobrowolne rolnik podejmuje, kiedy chce uzyskać odpowiednie środki finansowe pochodzące ze środków europejskich. Współcześnie można do nich zaliczyć przykładowo regulacje dotyczące zazieleniania, czy polityki rozwoju obszarów wiejskich. Ograniczenia przymusowe są wprowadzane przez akt prawa publicznego. Część z nich wynika z Prawa ochrony środowiska, ustawy o ochronie przyro-

Natura 2000, [w:] Problemy wdrażania systemu Natura 2000 w Polsce, A. Kaźmierska-Patrzyczna, M.A. Król (red.), Szczecin - Łódź - Poznań 2013, s. 685-708; B. Jeżyńska, Obszary Natura 2000 w ramach Wspólnej Polityki Rolnej Unii Europejskiej, [w:] Problemy wdrażania systemu Natura 2000 w Polsce, A. Kaźmierska-Patrzyczna, M.A. Król (red.), Szczecin - Łódź - Poznań 2013, s. 709-721; M. Kłodziński, Sieć ekologiczna Natura 2000 a rozwój gospodarczy obszarów wiejskich, „Woda-Środowisko-Obszary Wiejskie”, t. 12, z. 1(37), 2012; A. Bołtromiuk, Możliwości i problemy rozwoju obszarów wiejskich objętych europejską siecią ekologiczną Natura 2000 - podsumowanie i rekomendacje, [w:] Europejska sieć ekologiczna Natura 2000 jako nowy element otoczenia polskiej wsi i rolnictwa, A. Bołtromiuk (red.), Warszawa 2010; A. Bołtromiuk, M. Zagórski, Natura 2000 - dobro publiczne, problem prywatny, Warszawa 2011. 
dy i innych aktów określonych w systemie prawa. Tym ograniczeniom rolnik musi się poddać pod groźbą określonych sankcji. Regulacje te niejednokrotnie zmieniają przeznaczenie nieruchomości - z typowo rolnej na użytki zielone, na których co do zasady nie można prowadzić intensywnej działalności rolniczej.

O ile regulacje europejskie dotyczące przyznawanej pomocy pozostawiają rolnikowi pewien margines wyboru, czy określone działania staną się jego udziałem, o tyle wspomniane regulacje prawa publicznego wynikające z ustawy o ochronie przyrody, czy innych aktów prawnych, nie pozostawiają wiele marginesu do swobodnego kształtowania przez rolnika treści i zakresu jego prawa własności. ${ }^{23}$

Powyższe twierdzenie umocnione jest współczesnymi poglądami doktryny prawa rolnego, która wskazuje, iż istnieje „kompleks przepisów, które wpływają w sposób pośredni na możność korzystania przez rolnika z jego własności. Suma tych regulacji określa sytuację prawną rolnika". ${ }^{24} \mathrm{Na}$ sumę obecnych regulacji składa się prawo europejskie i krajowe. Zresztą jako przykład takich przepisów Małgorzata Korzycka i Stanisław Prutis wskazują możliwość uzyskiwania płatności bezpośrednich, ale przy spełnieniu wymogów wzajemnej zgodności, które zakładają także zachowanie wymogów dotyczących ochrony środowiska. ${ }^{25}$ Do tych zasad współcześnie należałoby dołożyć wymogi określone w przywołanym rozporządzeniu 1307/2013 oraz w regulacjach związanych z rozwojem obszarów wiejskich. Należy zwrócić uwagę, że płatności bezpośrednie i środki pomocowe pochodzące z Programu Rozwoju Obszarów Wiejskich są instrumentami dobrowolnymi dla rolnika. Oznacza to, że rolnik sam decyduje się na przyjęcie tych rozwiązań prawnych, a co za tym idzie ograniczeń w wykonywaniu swojego prawa własności w zamian za określone środki finansowe.

Źródła ograniczeń mogą wypływać zarówno z regulacji europejskich, jak i krajowych. Na ich przykładowy katalog wskazuje się w nauce prawa rolnego. Podkreśla się, że ,istotny wpływ na wykonywania prawa mają normy z zakresu ochrony środowiska, ochrony gruntów rolnych, planowania przestrzennego, ale też prawa

Można zaliczyć tutaj jedynie uprawnienie do udziału w tworzeniu aktów planistycznych, czy ochronnych na etapie ich konsultacji. Por. także M. Micińska, Udział społeczeństwa w ochronie środowiska, Toruń 2011; Z. Cichocki, J. Stankiewicz J., Ochrona przyrody w świetle wdrażania zobowiązań międzynarodowych a udział społeczności lokalnej w podejmowaniu decyzji, [w:] Prawo ochrony przyrody. Stan obecny, problemy, perspektywy, D. Kopeć, N,. Ratajczyk (red.), Łódź 2008; B. Draniewicz, Uprawnienia organizacji ekologicznych w postępowaniach wymagających udziału społeczeństwa, „Monitor Prawniczy” 2011, nr 1; S.C.F. de Piérola, Natura 2000 i społeczeństwo: instrumenty komunikacji społecznej w zarządzaniu Siecią Natura 2000, Warszawa 2009. M. Korzycka-Iwanow, S. Prutis, Własność rolnicza, [w:] Prawo rolne, P. Czechowski (red.), Warszawa 2015, s. 48; por. także Ewolucja pozycji właściciela indywidualnego gospodarstwa rolnego w PRL, A. Stelmachowski, P. Czechowski (red.), Warszawa 1989; W. Pańko, O prawie własności i jego współczesnych funkcjach, Katowice 1984; M. Korzycka Ochrona własności rolniczej, Warszawa 1979; M. Korzycka-lwanow, Ochrona własności rolniczej w nawiązaniu do koncepcji własności rolniczej Profesora Andrzeja Stelmachowskiego, „Studia luridica Agraria" 2011, t. IX, s. 123-127; E. Gniewek, J. Nadler, W. Pańko, A. Policiński, A. Stelmachowski, Przemiany własności ziemi w rolnictwie polskim, Wrocław 1974; A. Jurcewicz, Własność w ujęciu prawa wspólnotowego - zarys, „Studia luridica Agraria” 2005, t. V. 
budowlanego, energetycznego, przepisy o opodatkowaniu działów specjalnych, ulgach podatkowych i inne". ${ }^{26}$ Do tych innych można zaliczyć zarówno regulacje przywołanych powyżej rozporządzeń 1307/2013 czy 1305/2013, ale także unormowania zawarte w Prawie ochrony środowiska, czy ustawie o ochronie przyrody. Prawo do ochrony przyrody oraz uregulowania europejskie wprowadzające nowe wymogi i kryteria dostępowe do pomocy staje się jednym z elementów kompleksu obowiązków rolnika związanych z własnością rolniczą.

Jak już podkreślono środki te powinny w znacznym stopniu rekompensować nałożone na rolnika obowiązki względem społeczeństwa. Wynika to przede wszystkim z publicznoprawnych źródeł tych obowiązków - czy to z regulacji europejskich, czy krajowych. Tam gdzie organ administracji publicznej ingeruje w prawo właściciela powinien przewidzieć możliwość ubiegania się przez niego o odpowiednie odszkodowanie. Mechanizmy kompensacyjne nie powinny w żaden sposób czynić z takich możliwości tylko teoretycznych rozwiązań, gdzie rolnik ma zapewnione możliwości prawne, ale praktyka stosowania prawa i wysokość rekompensat nie pozwalają w żaden sposób prowadzić działalności rolniczej. Zakreślone problemy dotyczące wysokości chociażby dopłat za zazielenianie są tego bardzo dobrym przykładem. De lege ferenda, ale także de lege lata należy wyraźnie zaznaczyć, że odszkodowania powinny być słuszne, jak wskazuje to norma konstytucyjna. Wymagając od rolnika określonych zachowań i powinności związanych z ochroną środowiska naturalnego należy mieć na względzie wynagrodzenie go za ponoszone ciężary względem społeczeństwa.

Opisując swoją koncepcję własności rolniczej Andrzej Stelmachowski również zwraca uwagę na element obowiązku państwa względem rolnika, który miałby polegać nie tylko na współpracy z rolnikiem, ale także na odpowiedniej pomocy dla niego. W koncepcji własności rolniczej wyraźnie wskazano, iż ,z faktu, że własność rolnicza odnosi się do mienia, a więc do kompleksu praw i obowiązków, wynika, że własność rolnicza jest kompleksem praw i obowiązków. Właściciel ma w stosunku do innych nie tylko prawa, ale i obowiązki. Cechą charakterystyczną własności rolniczej jest, że wspomniane obowiązki odnoszą się nie tylko do określonych jednostek, ile wobec państwa reprezentującego interes społeczeństwa jako całości. W zamian za należyte wykonywanie własności rolniczej właściciel ma prawo liczyć na pomoc (ze strony państwa) przy wykonywaniu swego prawa własności" ${ }^{27}$ Rolnik powinien mieć stworzone realne możliwości prawne skorzystania z pomocy państwa, które w imię realizacji celów ogółu stworzy mu takie warunki, aby ponoszone ciężary i ograniczenia mogły zostać skompensowane.

26 M. Korzycka-Iwanow, S. Prutis, Ochrona własności rolniczej, [w:] Prawo rolne, P. Czechowski (red.), Warszawa 2015, s. 49-50.

27 A. Stelmachowski, Treść i wykonywanie prawa własności, [w:] System Prawa Prywatnego, Prawo rzeczowe, T. Dybowski (red.), Warszawa 2007, t. 3, s. 189. 
To prawo powszechnie obowiązujące - prawo publiczne powinno nie tylko wymagać od rolnika określonych zachowań, ale także gwarantować mu bezpieczeństwo, prawne oraz ekonomiczne, w sytuacji kiedy on wykona nałożone na niego obowiązki. Rolnik zgodnie z koncepcją własności rolniczej powinien zaakceptować wprowadzone ograniczenia, jeżeli będą one służyły wykonywaniu obowiązków rolnika względem społeczeństwa. Niewątpliwie za taki obowiązek można uznać dbanie o stan środowiska naturalnego, w szczególności na obszarach cennych przyrodniczo. Zachowanie dóbr, które co do zasady są nieodnawialne, wydaje się w stanie obecnego postępu technologicznego, nieuchronną powinnością każdego obywatela, a rolnika w szczególności, jako że jest podmiotem, który w znacznym stopniu oddziałuje na te tereny.

Koncepcja własności rolniczej zakłada mechanizmy ochrony tej własności ${ }^{28}$ określone zarówno w przepisach cywilistycznych, jak również publicznoprawnych. Tak jak w przypadku ochrony przyrody obowiązuje zasada maksymalizacji ochrony, tak w przypadku ochrony warsztatu pracy rolnika współczesne prawo wydaje się znacznie niwelować jej poziom. Moim zdaniem pomiędzy tymi regulacjami powinna zachodzić równowaga, aby nie okazało się, że rolnik i jego pozycja ustrojowa jest w gorszym położeniu niż ochrona środowiska naturalnego.

Cechą niezwykle ciekawą koncepcji własności rolniczej jest właśnie dbanie o odpowiedni poziom ochrony rolnika. Co prawda zakłada się, że jest on w szczególnej pozycji i ma określone obowiązki, znacznie wykraczające poza wykonywanie prawa własności, ale wskazuje się, że rolnik w zamian za wykonywanie tych obowiązków może liczyć na pomoc państwa. Moim zdaniem odpowiedzialność państwa nie ma tutaj określonej granicy przez co powinna być odpowiedzialnością pełną i zupełną. Rolnik powinien wiedzieć, że organ administracji publicznej, co prawda, będzie żądał od niego określonych zachowań, ale w zamian będzie mógł liczyć na jego pomoc. Koncepcja Andrzeja Stelmachowskiego nakłada na państwo obowiązek zabezpieczenia prawa własności nieruchomości poprzez stworzenie takiego systemu prawnego, który będzie nie tylko wprowadzał obowiązki dla właścicieli nieruchomości rolnych, ale także będzie dla nich pomocą. Państwo powinno oferować nie tylko rekompensaty pieniężne, czy odpowiednio wysoki system dopłat, ale powinno pomagać rolnikowi, od którego wymaga określonych zachowań, we wszelkich możliwych sprawach związanych z prowadzoną działalnością rolniczą. Rolnik nie może zostać z nudum ius (gołym prawem), ${ }^{29}$ ale powinien mieć zagwarantowaną prawną możliwość ochrony swojego warsztatu pracy.

Współczesne regulacje zarówno europejskie, jak i krajowe wydają się nie zapewniać odpowiedniego poziomu ochrony rolnika oraz jego warsztatu pracy. Nie 
chronią również własności nieruchomości rolnych, dając pierwszeństwo publicznoprawnym celom ochrony środowiska. Oferowana w zamian za wprowadzane ograniczenia pomoc finansowa wydaje się niewystarczająca dla utrzymania odpowiedniego poziomu dochodów rolniczych.

W regulacjach dotyczących ochrony środowiska obowiązuje zasada kompensacji przyrodniczej. Oznacza ona konieczność podjęcia takich działań przez osobę wyrządzającą szkodę w środowisku, aby z naddatkiem przywrócić stan poprzedni lub jeżeli to jest niemożliwe inaczej zrekompensować przyrodzie negatywne działania. Zasada ta nie obowiązuje niestety w odwrotną stronę. Mechanizmy prawne nie zapewniają odpowiedniego poziomu rekompensat rolnikom, którzy w wyniku zastosowania zasad ochrony przyrody doznali znacznych strat finansowych lub musieli zaprzestać prowadzenia działalności rolniczej. W tym zakresie zasada zrównoważonego rozwoju doznaje uszczerbku na niekorzyść przedsięwzięć o charakterze gospodarczym.

W powyższej analizie wykazano także, że we współczesne problemy relacji zasad ochrony przyrody oraz ochrony warsztatu pracy rolnika wpisuje się koncepcja własności rolniczej Andrzeja Stelmachowskiego. Już prawie 70 lat temu dostrzeżono, że rolnik powinien mieć względem społeczeństwa obowiązki wynikające z jego specjalnego statusu jako właściciela nieruchomości rolnych. To twierdzenie nadal jest aktualne, nawet pomimo zmiany ustroju państwa. Dziś rolnik ma obowiązki względem społeczeństwa polegające nie tylko na dostarczeniu produktów rolnych celem zaspokojenia potrzeb żywieniowych, ale także obowiązki wynikające z troski o zachowanie środowiska naturalnego. Należy jednakże podkreślić, że koncepcja własności rolniczej zakłada pomoc dla rolnika w zamian za ponoszone przez niego ciężary. Obecnie regulacje publicznoprawne takiej pomocy nie gwarantują na odpowiednim poziomie. De lege ferenda należałoby zalecić europejskiemu i krajowemu prawodawcy równomierne nakładanie na rolników obowiązków i środków kompensacyjnych. Bez zachowania takiej miary nie będzie możliwe zrealizowanie prośrodowiskowych celów Wspólnej Polityki Rolnej ani do 2020 r., ani w bliżej określonej przyszłości. 
PROTECTION OF THE ENVIRONMENT IN THE PROCESS OF AGRICULTURAL PRODUCTION AND THE CONCEPT OF AGRICULTURAL PROPERTY

Keywords: environmental protection, agricultural property, Andrzej Stelmachowski, Natura 2000

The article indicates the basic principles of environmental protection used in agricultural law in the light of European and national regulation. This paper focuses also on the analysis of the impact of modern environmental law on ownership of agricultural real estate and agricultural activities. What is more, new obligations for farmers has been analyzed in the context of the Andrzej Stelmachowski's concept of agricultural property.

\section{Bibliografia:}

Anderson G., Śleszyński J., Ekonomiczna wycena środowiska przyrodniczego, [w:] Wartościowanie dóbr i zasobów środowiska, J. Śleszyński (red.), Białystok 1996.

Bołtromiuk A., Możliwości i problemy rozwoju obszarów wiejskich objętych europejską siecią ekologiczną Natura 2000 - podsumowanie i rekomendacje, [w:] Europejska sieć ekologiczna Natura 2000 jako nowy element otoczenia polskiej wsi i rolnictwa, A. Bołtromiuk (red.), Warszawa 2010.

Bołtromiuk A., Zagórski M., Natura 2000 - dobro publiczne, problem prywatny, Warszawa 2011.

Borysiak W., Ochrona własności a nadużycie prawa, „Studia Iuridica” 2010, nr 52.

Budzikowski M., Ograniczenia praw podmiotowych właściciela nieruchomości rolnej w prawie administracyjnym, „Studia Iuridica” 2014, nr 58.

Bukowski Z., Wybrane uwarunkowania prawne odnoszące się do obszarów Natura 2000 stanowiących park narodowy, [w:] Problemy wdrażania systemu Natura 2000 w Polsce, A. Kaźmierska-Patrzyczna, M.A. Król (red.), Szczecin - Łódź - Poznań 2013.

Cichocki Z., Stankiewicz J., Ochrona przyrody w świetle wdrażania zobowiązań międzynarodowych a udział społeczności lokalnej w podejmowaniu decyzji, [w:] Prawo ochrony przyrody. Stan obecny, problemy, perspektywy, D. Kopeć, N. Ratajczyk (red.), Łódź 2008.

Ciechanowicz McLean J., Parki Narodowe w prawnym systemie ochrony przyrody, [w:] Administracja publiczna a ochrona przyrody. Zagadnienia ekonomiczne, społeczne oraz prawne, M. Górski, D. Niedziółka, R. Stec, D. Strus (red.), Warszawa 2012.

Czechowski P., Niewiadomski A., National parks and Natura 2000 areas - evaluation of the legal status of regulations in rural areas, [w:] Chosen Problems of Nature Conservation in Polish and International Law, P. Litwiniuk, A. Niewiadomski, R. Stec, Ł. Ciołek (red.), Warszawa 2015.

Czechowski P., Niewiadomski A., Natura 2000 a parki narodowe - wybrane problemy prawne, [w:] Administracja publiczna a ochrona przyrody. Zagadnienia ekonomiczne, społeczne oraz prawne, M. Górski, D. Niedziółka, R. Stec, D. Strus (red.), Warszawa 2012. 
Czechowski P., Niewiadomski A., Selected legal issues of modern forms of environmental protection on the example of national parks and the networks of Natura 2000 sites, taking into account coexistence with agriculture, ,Studia Iuridica” 2015, t. 61.

Czechowski P., Niewiadomski A., Wpływ funduszy strukturalnych na wzrost konkurencyjności polskiego rolnictwa - aspekty prawne, „Studia Iuridica Agraria” 2012, t. X.

Czubak W., Poczta W., Sadowski A., Wpływ proponowanej reformy systemu dopłat bezpośrednich po 2013 roku na sytuację polskiego rolnictwa, „Wieś i rolnictwo” 2011, nr 4.

Draniewicz B., Uprawnienia organizacji ekologicznych w postępowaniach wymagających udziału społeczeństwa, „Monitor Prawniczy” 2011, nr 1.

Ewolucja pozycji właściciela indywidualnego gospodarstwa rolnego w PRL, A. Stelmachowski, P. Czechowski (red.), Warszawa 1989.

Germano A., Reforma Wspólnej Polityki Rolnej z 2003 r. i reżim płatności jednolitej, „Przegląd Prawa Rolnego" 2007, nr 1.

Gniewek E., Nadler J., Pańko W., Policiński A., Stelmachowski A., Przemiany własności ziemi w rolnictwie polskim, Wrocław 1974.

Gniewek E., O prawie własności - w kontekście prac Komisji Kodyfikacyjnej Prawa Cywilnego, „Rejent" 2008, nr 2.

Gocłowski M., Posiadanie w ujęciu kodeksu cywilnego (Prawo podmiotowe czy stan faktyczny?), „Państwo i Prawo” 2001, nr 2.

Hawrylewicz-Łuka A., Spełnianie wymogów wzajemnej zgodności (cross-complience) przy ubieganiu się przez rolników o płatności bezpośrednie jako poszanowanie środowiska naturalnego, [w:] Administracja publiczna - człowiek a ochrona środowiska. Zagadnienia społeczno-prawne, M. Górski, J. Bucińska, M. Niedziółka, R. Stec, D. Strus (red.), Warszawa 2011.

Jeżyńska B., Obszary Natura 2000 w ramach Wspólnej Polityki Rolnej Unii Europejskiej, [w:] Problemy wdrażania systemu Natura 2000 w Polsce, A. Kaźmierska-Patrzyczna, M.A. Król (red.), Szczecin - Łódź - Poznań 2013.

Jeżyńska B., Proekologiczne instrumenty wsparcia zrównoważonego rozwoju obszarów Wiejskich, „Studia Iuridica Agraria”2012, t. X.

Jeżyńska B., Znaczenie i funkcje zasady cross-compliance w systemie rolniczych dopłat bezpośrednich, „Studia Iuridica Lubliniensia” 2010, nr 13.

Jurcewicz A., Własność w ujęciu prawa wspólnotowego - zarys, „Studia Iuridica Agraria” 2005, t. 5.

Jurcewicz A., Wspólna Polityka Rolna Unii Europejskiej, [w:] Prawo rolne, P. Czechowski (red.), Warszawa 2011.

Kłodziński M., Sieć ekologiczna Natura 2000 a rozwój gospodarczy obszarów wiejskich, „Woda-Środowisko-Obszary Wiejskie" 2012, t. 12, z. 1(37).

Kokoszka D., Gospodarstwo rolne. Zagadnienia konstrukcyjne, „Kwartalnik Prawa Prywatnego” 2008, $\mathrm{nr} 4$.

Korzycka M., Ochrona własności rolniczej, Warszawa 1979.

Korzycka-Iwanow M., Ochrona własności rolniczej w nawiązaniu do koncepcji własności rolniczej Profesora Andrzeja Stelmachowskiego, „Studia Iuridica Agraria” 2011, t. IX.

Korzycka-Iwanow M., Prutis S., Własność rolnicza, [w:] Prawo rolne, P. Czechowski (red.), Warszawa 2015.

Kremer E., Wybrane zagadnienia z problematyki rozwoju obszarów wiejskich, płatności bezpośrednich w orzecznictwie sądów administracyjnych, „Studia Iuridica Agraria” 2009, t. VII. 
Król M.A., Niewiadomski A., Rodzinne gospodarstwa rolne w systemie prawnym ochrony środowiska i zrównoważonego rozwoju, [w:] Ekonomiczne i prawne mechanizmy wspierania i ochrony rolnictwa rodzinnego, M. Podstawka (red.), Warszawa 2015.

Król M.A., Sytuacja prawna prowadzącego działalność rolniczą na obszarach Natura 2000, [w:] Problemy wdrażania systemu Natura 2000 w Polsce, A. Kaźmierska-Patrzyczna, M.A. Król (red.), Szczecin - Łódź - Poznań 2013.

Kurowska T., Współczesne aspekty własności rolniczej, „Studia Iuridica Agraria” 2002, t. III.

Kurowska T., Zadania i funkcje instrumentów prawnych wspierania rozwoju obszarów wiejskich, „Studia Iuridica Agraria” 2005, t. IV.

Longchamps F., Ograniczenia własności nieruchomości w polskim prawie administracyjnym, „Przegląd Prawa i Administracji” 1939, nr 1-2.

Micińska M., Udział społeczeństwa w ochronie środowiska, Toruń 2011.

Niewiadomski A., Rodzinne gospodarstwo rolne wobec ochrony środowiska w prawie polskim i europejskim, [w:] Prawne mechanizmy wspierania i ochrony rolnictwa rodzinnego w Polsce i innych państwach Unii Europejskiej, P. Liwtiniuk (red.), Warszawa 2015.

Nowak A.Z., Niewiadomska A., Wpływ funduszy strukturalnych na wzrost konkurencyjności polskiego rolnictwa - wybrane aspekty ekonomiczne, ,Studia Iuridica Agraria” 2012, t. X.

Pańko W., O prawie własności i jego współczesnych funkcjach, Katowice 1984.

Piekut K., Pawluśkiewicz B., Stan i perspektywy utrzymania obszarów Natura 2000 na terenach rolniczych, [w:] Problemy wdrażania systemu Natura 2000 w Polsce, A. Kaźmierska-Patrzyczna, M.A. Król (red.), Szczecin - Łódź - Poznań 2013.

Piérola S.C.F. de, Natura 2000 i społeczeństwo: instrumenty komunikacji społecznej w zarządzaniu Siecią Natura 2000, Warszawa 2009.

Radecki W., Ograniczenie własności ze względu na potrzeby szczególnej ochrony przyrody, [w:] Ochrona środowiska a prawo własności, J. Sommer (red.), Wrocław 2000.

Stelmachowski A., Przedmiot własności w prawie cywilnym, „Studia Iuridica” 1994, nr 21.

Stelmachowski A., Treść i wykonywanie prawa własności, [w:] System Prawa Prywatnego, Prawo rzeczowe, T. Dybowski (red.), Warszawa 2007, t. 3.

Stelmachowski A., Współczesne zróżnicowanie własności, „Studia Iuridica Agraria” 2002, t. III.

Stelmachowski A., Wstęp do teorii prawa cywilnego, Warszawa 1969.

Stelmachowski A., Zarys teorii prawa cywilnego, Warszawa 1998.

Stoksik J., Wybrane zagadnienia ochrony interesów finansowych Unii Europejskiej w dziedzinie Wspólnej Polityki Rolnej, „Studia Iuridica Agraria” 2012, t. X.

Szewczyk M., Ingerencja publicznoprawna w prawo własności jednostki w demokratycznym państwie prawnym, [w:] Jednostka w demokratycznym państwie prawa, J. Filipek (red.), Bielsko-Biata 2003.

Ura E., Heliniak K., Ograniczenia własności nieruchomości w administracyjnym prawie materialnym, [w:] Jednostka wobec działań administracji publicznej, E. Ura (red.), Rzeszów 2001.

Waśniewski R., Pracownicze ogrody działkowe w prawie cywilnym i rolnym, „Państwo i Prawo” 2000, nr 5.

Wójcik S., Problem pojęcia “własność prywatna” w III Rzeczypospolitej, „Rejent” 1991, nr 7.

Wpływ instrumentów prawnych na przestrzenną strukturę rolnictwa, A. Stelmachowski (red.), Warszawa 1977. 
Ochrona środowiska naturalnego w procesie produkcji rolnej a koncepcja własności rolniczej

Zdziennicki B., Reprywatyzacja w świetle zasad prawa, „Studia Prawnicze” 2015, nr 3.

Zieliński A., Zagadnienia prawa własności w orzecznictwie Naczelnego Sądu Administracyjnego, „Kwartalnik Prawa Prywatnego 1993, nr 4. 